\title{
Oxidative and cytotoxic stress induced by inorganic granular and fibrous particles
}

\author{
SIMONE HELMIG $^{1 *}$, DIRK WALTER ${ }^{1 *}$, JULIA PUTZIER $^{1}$, HAGEN MAXEINER $^{2}$, \\ SIBYLLE WENZEL ${ }^{1}$ and JOACHIM SCHNEIDER ${ }^{1}$
}

\author{
${ }^{1}$ Institute and Outpatient Clinic for Occupational and Social Medicine, Justus-Liebig University; \\ ${ }^{2}$ Department of Anaesthesiology, Intensive Care Medicine and Pain Therapy, University Hospital Giessen and Marburg, \\ Campus Giessen, D-35392 Giessen, Germany
}

Received July 6, 2017; Accepted February 27, 2018

DOI: $10.3892 / \mathrm{mmr} .2018 .8923$

\begin{abstract}
The hazards of granular and fibrous particles have been associated with the generation of reactive oxygen species (ROS), which in turn is often associated with physicochemical properties exhibited by these particles. In the present study, the ability of various types of fibrous and granular dusts to generate oxidative stress, and their cytotoxicity, was investigated. Biopersistent granular dusts employed in the present study included micro- and nanosized titanium dioxide with rutile or anatase crystal structure modifications. Additionally, glass fibres, chrysotile and crocidolite asbestos representative of fibrous dust were selected. Detailed characterisation of particles was performed using scanning electron microscopy, and the effect of exposure to these particles on cell viability and intracellular ROS generation was assessed by PrestoBlue and 2',7'-dichlorofluorescein assays, respectively. A549 human lung epithelial adenocarcinoma cells were exposed to increasing concentrations $\left(0.1-10 \mu \mathrm{g} / \mathrm{cm}^{2}\right)$ of particles and fibres for $24 \mathrm{~h}$. Subsequently, the gene expression of X-linked inhibitor of apoptosis (XIAP), superoxide dismutase (SOD)1 and SOD2 were analysed by reverse transcription-quantitative polymerase chain reaction. All investigated granular particles induce ROS production in A549 lung carcinoma cells within $24 \mathrm{~h}$. Hematite increased ROS production in a dose-dependent manner. A concentration of $>1 \mu \mathrm{g} / \mathrm{cm}^{2} \mathrm{TiO}_{2}$ na with its disordered surface, demonstrated the greatest ability to generate ROS. Therefore, the crystalline surface structure of the particle may be considered as a determinant of the extent of ROS induction by the particle. Fibrous particle compared
\end{abstract}

Correspondence to: Dr Simone Helmig, Institute and Outpatient Clinic for Occupational and Social Medicine, Justus-Liebig University, Aulweg 129, D-35392 Giessen, Germany

E-mail: simone.helmig@arbmed.med.uni-giessen.de

\section{*Contributed equally}

Key words: A459 cells, fibrous and granular particles, electron microscopy, cytotoxicity, ROS, oxidative stress, gene expression with granular particles were associated with a lower ability to generate ROS. Glass fibres did not significantly increase ROS production in A549 cells, but elevated gene expression of SOD2 was observed. The results demonstrated that in general, the ability of particles to generate ROS depends on their number and crystal phase. Therefore, the present study helps to understand the cause of particle toxicity.

\section{Introduction}

The term reactive oxygen species (ROS) refers to numerous reactive molecules and free radicals that are generated from molecular oxygen (1). These molecules are produced in all cell types as by-products of aerobic respiration or by oxidoreductase enzymes and metal-catalysed oxidation $(1,2)$. In addition to this endogenous source, ROS are also generated in response to exogenous stimuli, including particles and their interactions with cellular components (3). ROS may lead to various detrimental effects, but also function as important messengers for intra- and intercellular communication (2). The majority of eukaryotic cells possess an antioxidant defence system, including glutathione (GSH) and thioredoxin systems, which function alongside superoxide dismutase enzymes (SOD) (4-6). At low levels, ROS are readily neutralised by antioxidant defences, including GSH, SOD and antioxidant enzymes, which ensures a balance between the production and removal of ROS; however, conditions that lead to an imbalance, such as excessive ROS production, overwhelms the endogenous defences and is associated with the development of oxidative stress $(2,3)$. A hierarchical oxidative stress hypothesis associates low levels of oxidative stress with the activation of antioxidant and detoxification enzymes, while genes encoding phase II enzymes are reported to be regulated by transcription factors, such as the nuclear factor erythroid 2-related factor 2 (3).

At higher levels of oxidative stress, proinflammatory signalling cascades, including mitogen-activated protein kinase and nuclear factor $\kappa \mathrm{B}$ pathways, are activated, which leads to inflammation and cytotoxicity; mitochondrial perturbation and the release of proapoptotic factors subsequently occur to induce apoptosis $(1,3,7)$. Several particles may also target the mitochondria directly $(7,8)$. Due to the high reactivity of ROS, 
they damage the integrity of various biomolecules, including nucleic acids, proteins and lipids (9). The biological impact of ROS is dependent on the specific molecules involved, the microenvironment, the physiological or pathological context in which it is generated in, and the magnitude and duration of exposure (9-11).

In particle toxicology research, the induction of ROS generation and oxidative stress is an important mechanism for particle-induced cytotoxicity $(12,13)$. Particles are either able to generate oxidants themselves or may stimulate the production of cellular oxidants (13). The hazards of granular and fibrous dust is often associated with their physicochemical properties, including size, surface properties, chemical composition, crystalline structure, solubility and aggregation (3). Based on their length-to-diameter ratio, particles may be divided into granular and fibrous dust. The toxicity of biopersistent granular dust may be due to biopersistence, which is also termed the particle effect, and not due to substance-specific properties. In an animal model, biopersistent granular dusts were reported to provoke lung cancer, but did not appear to be primarily genotoxic (14). Nanosized particles, defined by a diameter $<100 \mathrm{~nm}$, demonstrated a higher tendency to form agglomerates compared with their larger counterparts (15). The size of nanoparticles is comparable with the size of subcellular structures, including cell organelles and macromolecules (16). The high surface/mass ratios of these small particles accounts for their higher chemical reactivity (17).

In the present study the ability of different fibrous and granular dusts to generate ROS in a lung epithelial adenocarcinoma cell model was investigated using A549 cells. Glass fibres, and chrysotile and crocidolite asbestos, were selected as representatives of fibrous dust. Glass fibres are non-crystalline, synthetic, inorganic substances, that belong to the group of so-called man-made vitreous fibres. Asbestos is an established carcinogen associated with the promotion of lung cancer, mesothelioma and lung fibrosis (18). DNA damage and apoptosis are important downstream consequences of asbestos exposure that have been reported in all major studies addressing lung cells, as reported in a detailed review by Kamp (19). Exposure to asbestos fibres has been reported to induce altered cell signalling (20) and the stimulation of various proinflammatory molecules, including certain cytokines $(21,22)$. Crocidolite $\left[\mathrm{Na}_{2}\left(\mathrm{Fe}^{3+}\right)_{2}\left(\mathrm{Fe}^{2+}\right)_{3} \mathrm{Si}_{8} \mathrm{O}_{22}(\mathrm{OH})_{2}\right]$ has an iron content of $26 \%$, while the iron content of chrysotile $\left[\mathrm{Mg}_{6} \mathrm{Si}_{4} \mathrm{O}_{10}(\mathrm{OH})_{8}\right]$ is lower, ranging between 1 and $6 \%$, the majority of which is considered surface contamination (23). As biopersistent granular dust, microsized titanium dioxide anatase $\left(\mathrm{TiO}_{2} \mathrm{ma}\right)$, nanosized titanium dioxide anatase $\left(\mathrm{TiO}_{2}\right.$ na) and nanosized titanium dioxide rutile $\left(\mathrm{TiO}_{2} \mathrm{nr}\right)$ were selected to compare variations in size and crystal structure modifications. $\mathrm{TiO}_{2}$ is insoluble and rutile is chemically inert $(13,24)$, while, anatase is more reactive and cytotoxic due to its crystalline structure (25). Finally, nanosized hematite $\left(\alpha-\mathrm{Fe}_{2} \mathrm{O}_{3}\right)$ with an iron content of $\sim 70 \%$ was investigated due to its ability to induce ROS generation via the Fenton reaction (26-28).

As the ability to generate oxidative stress may be the crucial mechanism underlying particle-induced cytotoxicity, the hazards of particles may be associated with their physicochemical properties. Therefore, the particle properties that may be responsible for oxidative stress were investigated in the present study by analysing the ROS-generating potential of various particles. In addition, the gene expression of oxidative stress-associated genes involved in antioxidant defence processes and mechanisms was investigated.

\section{Materials and methods}

Dust material and characterisation. Chrysotile asbestos [Rhodesian NB \#4173-11-2; Union for International Cancer Control (UICC), Geneva, Switzerland] and crocidolite asbestos (South African NB \#4173-111-3; UICC) were used as standard references for recognised toxic fibrous dust. Fibrous glass (man-made vitreous fibres) representing biodurable fibres was obtained from commercial glass wool fibres used for insulation. $\mathrm{TiO}_{2}$ ma (www.sigmaaldrich.com/catalog/product/aldrich/ 232033?lang=de\&region=DE232033; Sigma-Aldrich; Merck KGaA, Darmstadt, Germany), $\mathrm{TiO}_{2}$ na (cat. no. NO-0038-HP; IoLiTec-Ionic Liquids Technologies GmbH, Heilbronn, Germany) and $\mathrm{TiO}_{2}$ nr (cat. no. NO-0046-HP; IoLiTec-Ionic Liquids Technologies $\mathrm{GmbH}$ ) represented biopersistent granular dust. Hematite ( $\alpha-\mathrm{Fe}_{2} \mathrm{O}_{3}$; cat. no. 544884; Sigma-Aldrich; Merck KGaA) was investigated to represent ultrafine particles.

Scanning electron microscopy (SEM; S-2700; Hitachi, Ltd., Tokyo, Japan) was employed to identify particle geometry and the microstructure of the samples. Element analysis was conducted using energy dispersive X-ray spectroscopy (EDX). To optimise the conductivity (electron beam), all samples were coated with a very fine gold layer using the sputtering technique. Transmission electron microscopy (TEM) analysis combined with EDX, as well as electron diffraction (detection of crystallinity), was conducted using a transmission electron microscope H-7100 (Hitachi, Ltd.). A detailed description of the characterisation method is described in our previous study (29). Thermogravimetry (TG) measurements (corundum crucibles, heating rate $5 \mathrm{~K} / \mathrm{min}$ and synthetic air atmosphere) for controlling volatile impurities, such as water, performed using a thermobalance TG 209 F1 Iris (Netzsch-Geräetebau GmbH, Selb, Germany) $(30,31)$.

For all experiments, an autoclaved stock solution with $5 \mathrm{mg}$ particles/ml PBS was prepared. Prior to each application the solutions were vortexed and sonicated.

Dosimetry. It is known that fibres and particles, depending on their size and mass, behave differently when added to cell culture medium, particularly with regards to the time it takes to settle down on cells following addition to medium, which is termed the sinking rate (32). To estimate the sinking velocities of each particle and fibre under experimental conditions, glass vessels were filled with $6 \mathrm{ml} \mathrm{H}_{2} \mathrm{O}$. Into each glass vessel particles of the highest concentration $\left(10 \mu \mathrm{g} / \mathrm{cm}^{2}\right)$ were added. At $0.5,1,2,5,10,30,60,120,240$ and 600 min time-points, an aliquot of $10 \mu \mathrm{l}$ was collected from the sample at a standardised position (1.5 $\mathrm{cm}$ above the bottom). SEM was used to count the number of particles within each aliquot, standardised to an area of $1 \mathrm{~mm}^{2}$. The percentage of agglomeration of particles left in the suspension was determined.

Cell culture and treatment. The A549 human lung epithelial adenocarcinoma cell line, with characteristics of alveolar epithelial type II cells, was employed in the present study. 
A549 cells (European Collection of Cell Cultures) were purchased from Sigma-Aldrich (Merck KGaA). Briefly, A549 cells were cultivated in complete growth medium at $37 \pm 1^{\circ} \mathrm{C}$ in an atmosphere of $5 \pm 0.5 \% \mathrm{CO}_{2}$ and $95 \%$ humidity. Complete growth medium consisted of RPMI-1640 cell culture medium (Gibco; Thermo Fisher Scientific, Inc., Waltham, MA, USA), $10 \%$ foetal calf serum (Gibco; Thermo Fisher Scientific, Inc.) and $2 \mathrm{mM}$ L-glutamine (PAA Laboratories; GE Healthcare, Chicago, IL, USA). Cells were cultured until $\sim 75 \%$ confluent and subsequently rinsed with PBS, followed by dislodging with TrypLE Express (Thermo Fisher Scientific, Inc.). Cells were plated in 6-well plates at a density of 100,000 cells/well. Culture medium was replaced with fresh medium and cells were exposed to particles or fibres $24 \mathrm{~h}$ prior to ROS-detection. Unexposed cells in one well served as internal negative controls, while five other wells were exposed to $0.1,0.5,1,5$ or $10 \mu \mathrm{g} / \mathrm{cm}^{2}$, of the respective particle or fibre for $24 \mathrm{~h}$ at $37^{\circ} \mathrm{C}$.

Cell viability test with PrestoBlue ${ }^{\circledR}$. Viable cells maintain a reducing environment within the cytosol. PrestoBlue uses the reducing ability of viable cells and allows the quantification of cell proliferation to determine the effects of various reagents on the viability of different cell types. PrestoBlue reagent contains a nonfluorescent blue compound that is cell-permeable; the reagent appears red and fluoresces within the reducing environment of a viable cell, which is detected via fluorescence or absorbance. A549 cells were plated in 96-well plates at a density of 15,200 cells/well. At $24 \mathrm{~h}$ prior to analysis, the culture medium was replaced with fresh medium and cells were exposed to particles or fibres of varying concentrations $\left(0.1,0.5,1,2.5,5\right.$ or $\left.10 \mu \mathrm{g} / \mathrm{cm}^{2}\right)$ at $37^{\circ} \mathrm{C}$. All experiments were replicated seven times (biological replicate); unexposed cells in each 96-well plate served as internal negative controls and each condition within one 96-well plate was repeated three times (technical replicate). Fluorescence was analysed using the Tecan i-control reader and software Magellan ${ }^{\mathrm{TM}} 6.0$ (Tecan Group, Ltd., Zurich, Switzerland).

Detection of ROS. Intracellular ROS generation was assessed using the fluorescent probe $2^{\prime}, 7^{\prime}$-dichlorofluorescein (DCF). Cells were plated in 6-well plates at a density of 100,000 cells/well. Culture medium was replaced with fresh medium and cells were exposed to particles or fibres $24 \mathrm{~h}$ prior to ROS-detection. Unexposed cells in one well served as internal negative controls, while five other wells were exposed to $0.1,0.5,1,5$ or $10 \mu \mathrm{g} / \mathrm{cm}^{2}$ of the respective particle or fibre. The membrane-permeable diacetate form, DCF-diacetate ( $\mathrm{H}_{2}$-DCF-DA; EMD Millipore, Billerica, MA USA), was added to the culture medium at a final concentration of $10 \mu \mathrm{M}$ and incubated for $30 \mathrm{~min}$ at $37^{\circ} \mathrm{C}$. Following penetration of the membrane, the acetate groups are removed and the resulting $\mathrm{H}_{2}$-DCF becomes isolated intracellularly. Intracellular ROS oxidises $\mathrm{H}_{2}$-DCF to yield the fluorescent product, DCF. Fluorescence intensity was measured in $\geq 80$ different cells per preparation and background was identified as an area without cells and subtracted from the signal. Fluorescence was analysed using a fluorescence microscope combined with a video imaging system (TILL Photonics GmbH, Gräfelfing, Germany). Fluorescence of the cells of each well was measured for $5 \mathrm{~min}$. The increase in fluorescence intensity per min during the stimulation time was compared to the alterations in fluorescence intensity per min of the internal control well. Each preparation was repeated six to eight times (biological replicate).

Reverse transcription-quantitative polymerase chain reaction $(R T-q P C R)$. For mRNA extraction, 3,000,000 cells were plated in $75 \mathrm{~cm}^{2}$ cell culture flasks (Greiner Bio-One International $\mathrm{GmbH}$, Kremsmünster, Austria) with $15 \mathrm{ml}$ previously aforementioned growth medium. Cells were exposed to $1 \mu \mathrm{g} / \mathrm{cm}^{2}$ chrysotile, crocidolite and glass fibres or $100 \mathrm{ng} / \mathrm{cm}^{2} \mathrm{TiO}_{2} \mathrm{ma}, \mathrm{TiO}_{2} \mathrm{nr}, \mathrm{TiO}_{2}$ na and hematite for $24 \mathrm{~h}$ at $37^{\circ} \mathrm{C}$. Cells were trypsinised for $\sim 30 \mathrm{sec}$ with $10 \mathrm{ml}$ $0.05 \%$ trypsin and incubated for $10 \mathrm{~min}$ at $37^{\circ} \mathrm{C}$ following two washes with PBS at $37^{\circ} \mathrm{C}$. Detached cells were subsequently resuspended in $5 \mathrm{ml}$ ice-cold PBS and centrifuged at $400 \mathrm{x} \mathrm{g}$ (without brakes) for $10 \mathrm{~min}$ at $4^{\circ} \mathrm{C}$. The centrifugation step was repeated with $1 \mathrm{ml}$ ice-cold PBS in $1.5 \mathrm{ml}$ Eppendorf tubes. RNA was extracted immediately with TRI Reagent ${ }^{\circledR}$ (Sigma-Aldrich; Merck KGaA) according to the manufacturer's protocol. Isolated RNA was resuspended in $10 \mu 1$ RNAse-free water. Each sample was treated twice with $2 \mu \mathrm{l}$ RNAse-free DNAse at $1 \mathrm{U} / \mu \mathrm{l}$ (Qiagen $\mathrm{GmbH}$, Hilden, Germany) for $10 \mathrm{~min}$ at $37^{\circ} \mathrm{C}$ to eliminate remaining DNA. The prepared RNA underwent RT as described previously (33). For quantitative comparison of mRNA levels, qPCR was performed using SYBR Green fluorescence in a LightCycler ${ }^{\circledR}$ System (Roche Diagnostics GmbH, Mannenheim, Germany). Amplification specificity was verified with melting curves. Negative and positive controls were included in each PCR reaction. Gene expression was compared with the mean of the expression of $\beta$-2-microglobulin, $\beta$-actin and hypoxanthine phosphoribosyltransferase as the housekeeping genes. Calculations of expression were performed with the $2^{-\Delta \Delta \mathrm{Cq}}$ method, as previously described (34). All samples were analysed as duplicates (technical replicate) and for each gene at least six independent biological replicates were performed. Primer sequences and specific primer annealing temperatures are presented in Table I. PCR reactions were conducted with a final volume of $20 \mu \mathrm{l}$ using $1 \mathrm{X}$ ABsolute qPCR SYBR Green Capillary Mixes (ABgene; Thermo Fisher Scientific, Inc.), $300 \mathrm{nM}$ primers and $2 \mu \mathrm{l}$ cDNA. The PCR conditions were as follows: Initial activation of the Taq-DNA polymerase for $15 \mathrm{~min}$ at $95^{\circ} \mathrm{C}$, followed by 45 cycles of $10 \mathrm{sec}$ denaturation at $95^{\circ} \mathrm{C}$, annealing for $15 \mathrm{sec}$ at the specific annealing temperature (Table I) and extension for $10 \mathrm{sec}$ at $72^{\circ} \mathrm{C}$. All measurements were made without information regarding sample origin.

Statistical analysis. Data are presented as the mean \pm standard error from $n=8$ different culture preparations. Statistical comparisons for ROS production results were performed by one-way analysis of variance followed by the Games-Howell post-hoc test. Statistical comparisons for mRNA expression results were performed by the Kruskal-Wallis test followed by Dunn-Bonferroni post-hoc tests. $\mathrm{P}<0.05$ was considered to indicate a statistically significant difference. All data analyses were performed using SPSS 17 for Windows (SPSS, Inc., Chicago, IL, USA). 
Table I. Primer sequences and primer-specific annealing temperature.

\begin{tabular}{|c|c|c|c|}
\hline Gene & $\begin{array}{l}\text { Sequence 5'-3' } \\
\text { (forward) }\end{array}$ & $\begin{array}{l}\text { Sequence 5'-3' } \\
\text { (reverse) }\end{array}$ & $\begin{array}{c}\text { Annealing } \\
\text { temperature }\left({ }^{\circ} \mathrm{C}\right)\end{array}$ \\
\hline $\mathrm{ACTB}^{\mathrm{a}}$ & CTGGAACGGTGAAGGTGACA & AAGGGACTTCCTGTAACAACGCA & 56 \\
\hline $\mathrm{B} 2 \mathrm{M}^{\mathrm{a}}$ & ACTGAATTCACCCCCACTGA & CCTCCATGATGCTGCTTACA & 63 \\
\hline HPRT $^{\mathrm{a}}$ & ATGCTGAGGATTTGGAAAGGG & GCACACAGAGGGCTACAATG & 61 \\
\hline $\mathrm{GPX} 2^{\mathrm{b}}$ & TAAGTGGGCTCAGGCCTCTCT & GGTCATAGAAGGACTTGGCAATG & 58 \\
\hline $\mathrm{GR}^{\mathrm{b}}$ & AGACCTATTCAACGAGCTTTACC & CCTGCAGCATTTCATCACACC & 58 \\
\hline GSTpi $^{b}$ & GGAGACCTCACCCTGTACCA & GGGCAGTGCCTTCACATAGT & 55 \\
\hline SOD $1^{\mathrm{b}}$ & AGGGCATCATCAATTTCGAG & TGCCTCTCTTCATCCTTTGG & 55 \\
\hline $\mathrm{SOD} 2^{\mathrm{b}}$ & AAGGGAGATGTTACAGCCCAGATA & TCCAGAAAATGCTATGATTGATATGAC & 58 \\
\hline $\mathrm{TRX} 1^{\mathrm{b}}$ & GGATGACTGTCAGGATGTTGC & ATTCATTAATGGTGGCTTCAAGC & 58 \\
\hline $\mathrm{TRXR}^{\mathrm{b}}$ & TGCCACTGGTGAAAGACCAC & CAAGAAATCCAGCGCACTCC & 57 \\
\hline TXNDC5 $^{\mathrm{b}}$ & TCGATGACACCATTGCAGAAG & TGCTGCAGATATTCCGTTCAG & 57 \\
\hline $\mathrm{XIAP}^{\mathrm{b}}$ & CCGTGCGGTGCTTTAGTTGT & TTCCTCGGGTATATGGTGTCTGAT & 58 \\
\hline NDRG $1^{b}$ & TGGAGATTGAGCGACCAATG & CACAGTCCGCCATCTTGAG & 55 \\
\hline \multicolumn{4}{|c|}{ 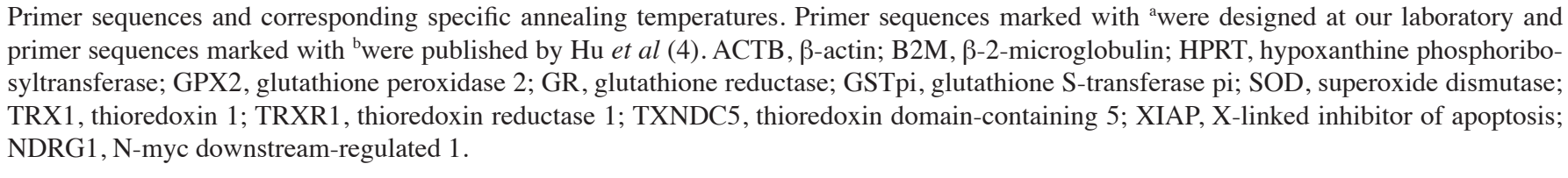 } \\
\hline
\end{tabular}

Table II. Characterisation of granular particles.

\begin{tabular}{lllcrrr}
\hline Particle & Size & Structure & Diameter aa, $\mu \mathrm{m}$ & $\mathrm{pp}, \mathrm{nm}$ & $\mathrm{pp} / \mathrm{aa}$ & $\mathrm{BET}, \mathrm{m}^{2} / \mathrm{g}$ \\
\hline $\mathrm{TiO}_{2} \mathrm{ma}$ & Microsized & Anatase & $1-3$ & $100-200$ & $\sim 20$ & 9.9 \\
$\mathrm{TiO}_{2} \mathrm{na}$ & Nanosized & Anatase & $0.1-2$ & $\sim 20$ & $10-500$ \\
$\mathrm{TiO}_{2} \mathrm{nr}$ & Nanosized & Rutile & $0.1-2$ & $\sim 20$ & $10-500$ & 5120 \\
$\mathrm{Hematite}$ & Nanosized & NA & $0.2-2$ & $\sim 20$ & $50-500$ \\
\hline
\end{tabular}

Characterisation of the granular dusts employed in the current study. aa, agglomerate/aggregate; pp, primary particles; pp/aa, number of primary particles per agglomerate/aggregate; $\mathrm{BET}$, Brunauer-Emmett-Teller surface area measurements; $\mathrm{TiO}_{2}$, titanium dioxide; TiO $\mathrm{T}_{2}$ ma, microsized $\mathrm{TiO}_{2}$ anatase; $\mathrm{TiO}_{2}$ na, nanosized $\mathrm{TiO}_{2}$ anatase; $\mathrm{TiO}_{2} \mathrm{nr}$, nanosized $\mathrm{TiO}_{2}$ rutile; $\mathrm{NA}$, not applicable.

\section{Results}

Characterisation of particles. $\mathrm{TiO}_{2}$ ma is irregularly shaped and crystalline. The microsized aggregates (diameter, 1-3 $\mu \mathrm{m}$ ) were composed of $\sim 20$ primary particles with a 100-200 nm diameter. The specific surface area (BET) of $\mathrm{TiO}_{2}$ ma was $9.9 \mathrm{~m}^{2} / \mathrm{g}$ (35). These details are summarised in Table II. A detailed characterisation of $\mathrm{TiO}_{2}$ ma is also provided in a previous manuscript (30).

$\mathrm{TiO}_{2}$ na consisted of $\sim 20 \mathrm{~nm}$ spherical agglomerated primary particles. Agglomerates of 0.1-2 $\mu \mathrm{m}$ were formed by 10-500 primary particles. The BET was specified as $>120 \mathrm{~m}^{2} / \mathrm{g}$. A circular diffraction pattern was observed for $\mathrm{TiO}_{2}$ na, indicating a lower state of crystallisation (disorder) compared to $\mathrm{TiO}_{2}$ nr (Fig. 1 and Table II). TiO 2 nr comprised $\sim 20 \mathrm{~nm}$ spherical agglomerated crystalline primary particles (Fig. 2). Agglomerates of 0.1-2 $\mu \mathrm{m}$ were formed by $10-500$ primary particles. The BET was specified with $50-150 \mathrm{~m}^{2} / \mathrm{g}$
(Table II). Hematite is a spherical formed, nanosized material. Agglomerates of $0.2-2 \mu \mathrm{m}$ were formed by $50-500$ primary particles with a diameter of $\sim 20 \mathrm{~nm}$ (Table II). Additionally, smaller aggregates $(<100 \mathrm{~nm})$ were detected by electron microscopy (data not shown). Hematite crystallises in different forms, including hexagonal flats, rod shapes and spherical forms. Due to precipitation reactions in aqueous solutions, additional water molecules can be incorporated into the crystal structure of hematite. The nanosized hematite used was selected as the anhydrous primary particles were of comparable sizes to both of the $\mathrm{TiO}_{2}$ nanoparticles used. Furthermore, the hematite nanoparticles are able to produce ROS by Fenton's reactions through to their iron (III) content. A detailed characterisation of nanosized hematite is provided in a previous manuscript (30). For the granular particles, volatile impurities are not observed by TG $(30,31)$. An overview of the granular particles characteristics is presented in Table II. 

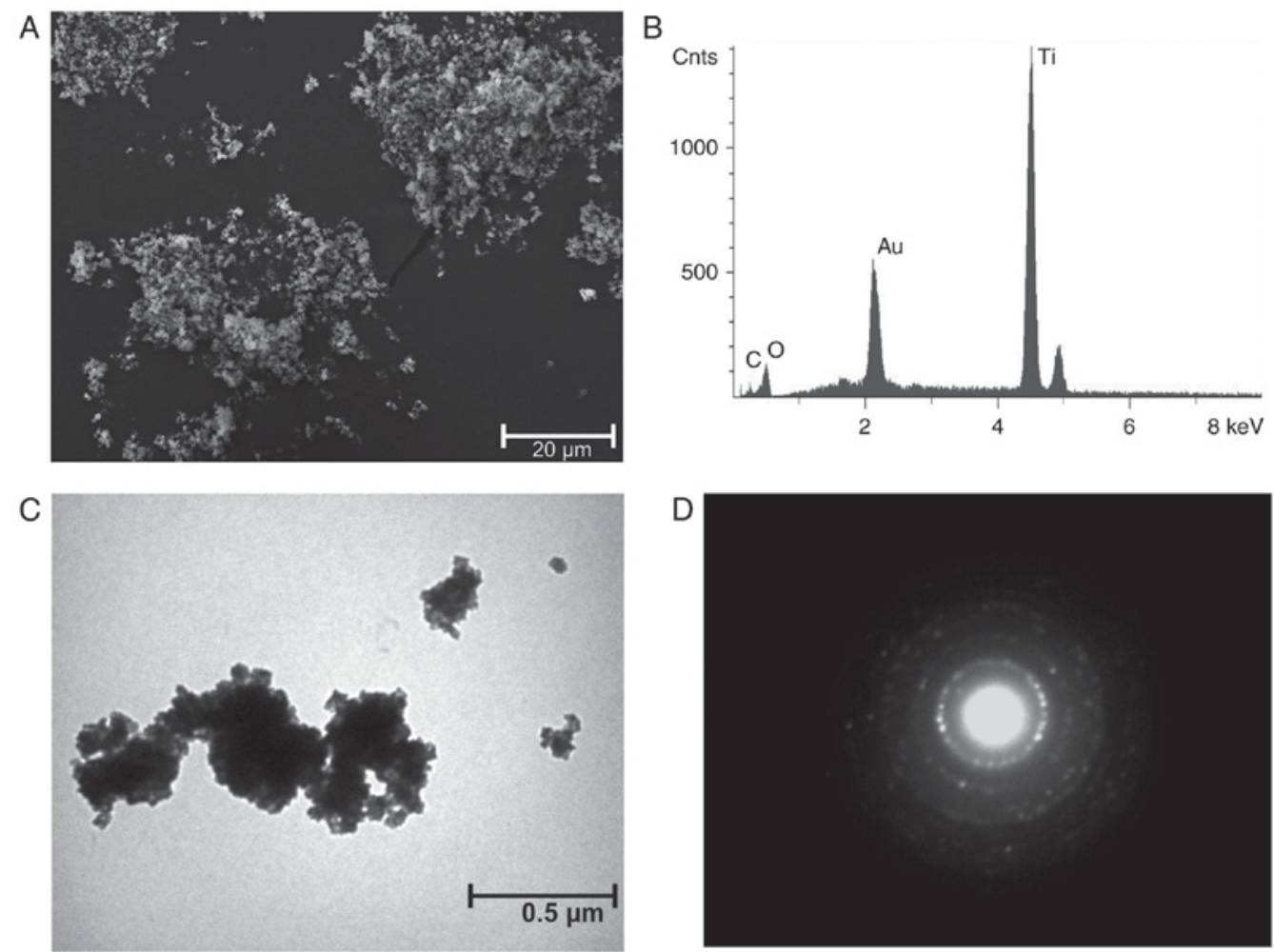

Figure 1. Nanosized titanium dioxide anatase. (A) Scanning electron microscopy (magnification, $\mathrm{x} 1,000$ ). (B) Results of energy dispersive X-ray spectroscopy analysis. (C) Transmission electron microscopy (magnification, x40,000). (D) Electron diffraction results.

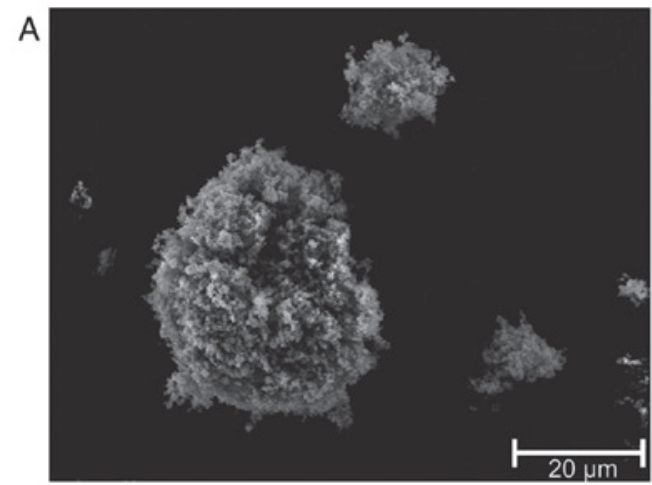

B
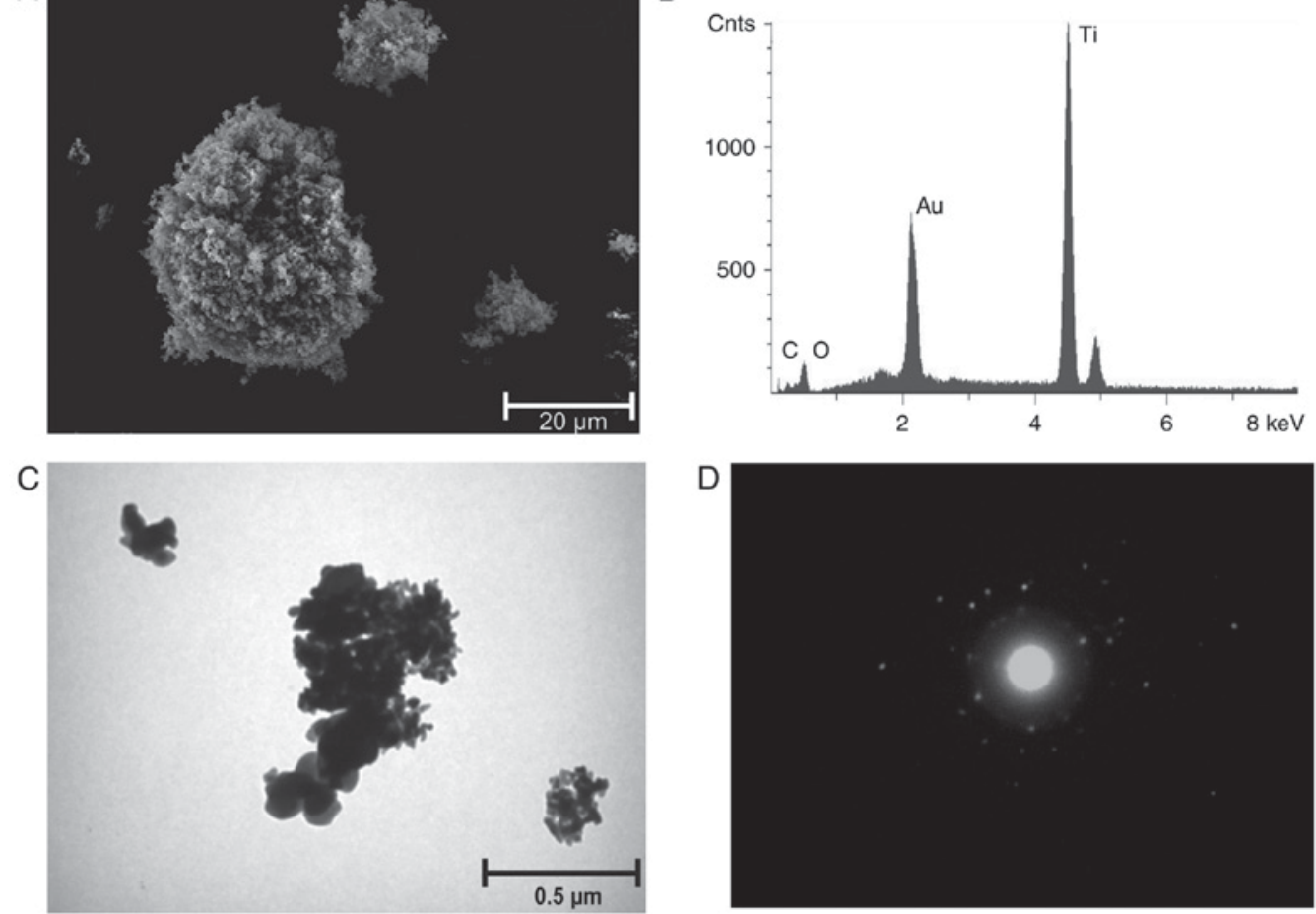

Figure 2. Nanosized titanium dioxide rutile. (A) Scanning electron microscopy (magnification, x1,000). (B) Results of energy dispersive X-ray spectroscopy analysis. (C) Transmission electron microscopy (magnification, $\mathrm{x} 40,000$ ). (D) Electron diffraction results.

The chemical composition, $70.0 \% \mathrm{SiO}_{2}, 14.3 \% \mathrm{CaO}$, 9.7\% $\mathrm{Na}_{2} \mathrm{O}, 2.5 \% \mathrm{MgO}, 2.3 \% \mathrm{~K}_{2} \mathrm{O}, 1.2 \% \mathrm{Al}_{2} \mathrm{O}_{3}$, of the glass fibres was detected by EDX analysis (Fig. 3). The WHO fraction [length of $>5 \mu \mathrm{m}$ and a diameter of $<3 \mu \mathrm{m}$; length: Diameter ration 3:1 (35)] of the fibres resulted in an average of $260,000 \mathrm{~F} / \mathrm{mg}$. The length to diameter ratio was $>3: 1$ 

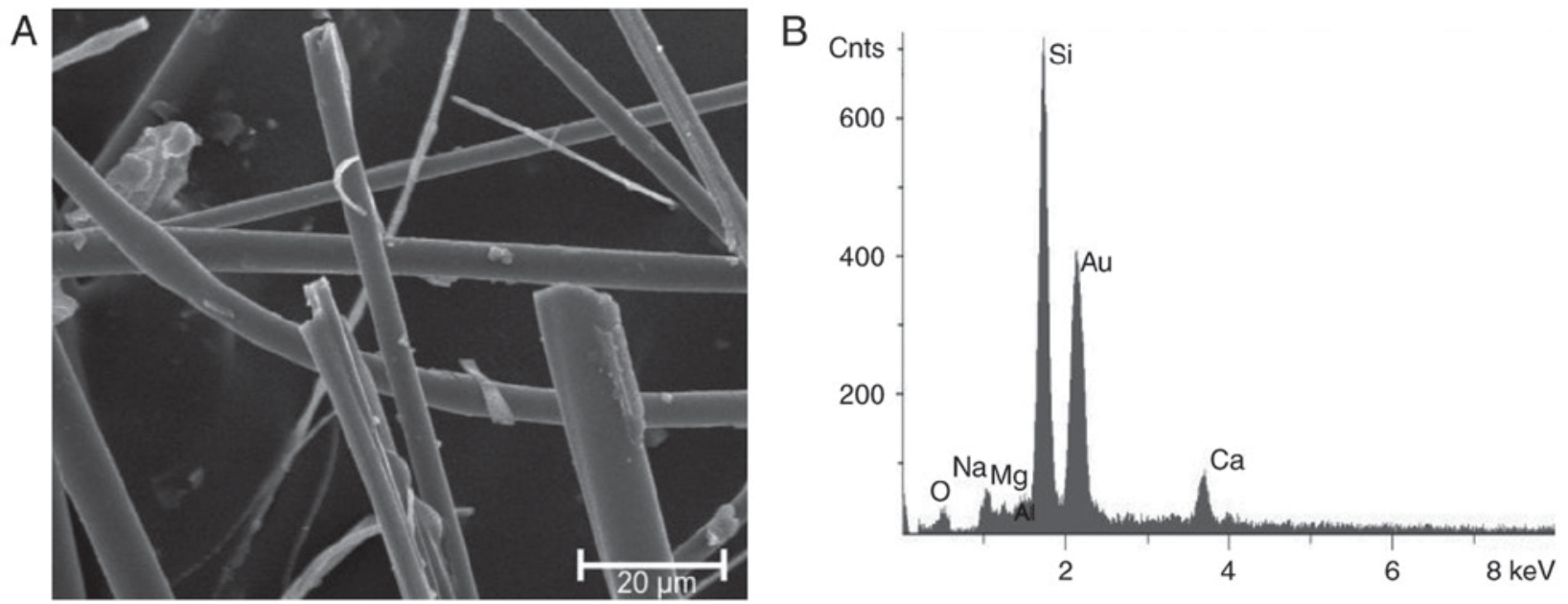

Figure 3. Glass fibre analysis. (A) Needle-like shaped glass fibres observed via scanning electron microscopy (magnification, x1,000). (B) Results of energy dispersive X-ray spectroscopy analysis.

(Table III). UICC chrysotile 'A' Rhodesian $\left[\mathrm{Mg}_{6}\left(\mathrm{Si}_{4} \mathrm{O}_{10}(\mathrm{OH})_{8}\right)\right]$ was demonstrated to have $800 \times 10^{6} \mathrm{~F} / \mathrm{mg}$ at a length of $>5 \mu \mathrm{m}$ and a diameter of $<3 \mu \mathrm{m}$. The length to diameter ratio was $>3: 1$ (WHO fraction; Table III). Chrysotile has a curly, pliable structure with close to equal $\mathrm{Mg} / \mathrm{Si}$ distribution. UICC crocidolite South African $\left[\mathrm{Na}_{2} \mathrm{Fe}_{3} \mathrm{Fe}_{2}\left(\mathrm{Si}_{8} \mathrm{O}_{22}(\mathrm{OH})_{2}\right)\right]$ was demonstrated to have $130 \times 10^{6} \mathrm{~F} / \mathrm{mg}$ at a length of $>5 \mu \mathrm{m}$ and a diameter of $<3 \mu \mathrm{m}$. The length to diameter ratio was $>3: 1$ (WHO fraction; Table III). Crocidolite is a rigid and rod-like fibre with characteristic iron content. A detailed characterisation of chrysotile asbestos (UICC, Rhodesian) and crocidolite asbestos (UICC, South African) is provided in a previous manuscript (30). An overview of the fibrous particles characteristics is presented in Table III.

Dosimetry of particles (Table IV). $\mathrm{TiO}_{2}$ ma particles (>90\%) settled out of the suspension onto the cell layer after $30 \mathrm{~min}$. After 30 and $240 \mathrm{~min}$, respectively, 60 and $>70 \%$ nanosized $\mathrm{TiO}_{2}$ particles $\left(\mathrm{TiO}_{2}\right.$ na $\mathrm{TiO}_{2}$ nr) settled out of the suspension onto the cell layer. For hematite particles, $\sim 30$ and $>90 \%$ settled out of the suspension onto the cell layer after 30 and $240 \mathrm{~min}$, respectively. Glass fibres ( 90\%) settled out of the suspension onto the cell layer after $5 \mathrm{~min}$. Following $240 \mathrm{~min}$ $>70 \%$ of the UICC chrysotile asbestos fibres settled out of the suspension onto the cell layer whereas following the same time period only $\sim 30 \%$ of the UICC crocidolite asbestos fibres settled out of the suspension onto the cell layer.

Cell viability. Cell viability was determined following the incubation at $37^{\circ} \mathrm{C}$ of A549 cells with granular or fibrous particles of varying concentrations $\left(0.1-10 \mu \mathrm{g} / \mathrm{cm}^{2}\right)$ over $24 \mathrm{~h}$. Loss of viability was not observed when A549 cells were exposed to the granular particles: $\mathrm{TiO}_{2}$ ma, $\mathrm{TiO}_{2} \mathrm{nr}, \mathrm{TiO}_{2}$ na and hematite (Fig. 4). Similar to the results for granular particles, no loss of cell viability was observed following incubation of cells with glass fibres. However, chrysotile and crocidolite markedly reduced cell viability at concentrations $\geq 5 \mu \mathrm{g} / \mathrm{cm}^{2}$ (Fig. 5).

ROS production following exposure to granular particles. All investigated granular particles significantly induced
ROS production in A549 lung carcinoma cells within $24 \mathrm{~h}$. Although the $\mathrm{TiO}_{2}$ species investigated in the present study have the same chemical composition, they differ in their size and crystal structure modification. Of the three $\mathrm{TiO}_{2}$ particles investigated, $\mathrm{TiO}_{2}$ na exhibited the greatest ability to generate ROS at concentrations $\geq 1 \mu \mathrm{g} / \mathrm{cm}^{2}$ and induced higher levels of ROS compared with hematite at concentrations $\geq 5 \mu \mathrm{g} / \mathrm{cm}^{2} . \mathrm{TiO}_{2} \mathrm{nr}$ particles generated significantly higher ROS in comparison with controls but exhibited the lowest level of ROS production of all nanosized particles investigated ( $\mathrm{TiO}_{2}$ na, $\mathrm{TiO}_{2} \mathrm{nr}$ and hematite). $\mathrm{TiO}_{2}$ ma particles induced high ROS production at a concentration of $10 \mu \mathrm{g} / \mathrm{cm}^{2}$, while lower concentrations generated ROS to a lower extent, which was comparable with the ROS generation of fibrous particles. Exposure to low concentrations $\left(<1 \mu \mathrm{g} / \mathrm{cm}^{2}\right)$ of granular particles, with the exception of hematite, induced relatively small increases in ROS. Above concentrations of $1 \mu \mathrm{g} / \mathrm{cm}^{2}, \mathrm{TiO}_{2}$ na, with its disordered surface (demonstrated by TEM diffraction in Fig. 1), exhibited the greatest ability to generate ROS. The nanosized $\mathrm{TiO}_{2}$ particles investigated $\left(\mathrm{TiO}_{2}\right.$ na and $\left.\mathrm{TiO}_{2} \mathrm{nr}\right)$ exhibit the same characteristics but differ in their structural modification. Comparing the ROS generation in A549 cells between both nanosized $\mathrm{TiO}_{2}$ particles revealed a statistically significant difference of $\mathrm{P}=0.02$. Therefore, the surface of the particle appears to be a modifying factor. Hematite induced ROS in a dose-dependent manner. Potentially due to the iron content of hematite, which induces ROS by Fenton's reaction, significant differences were revealed in comparison to $\mathrm{TiO}_{2}$ ma $(\mathrm{P}=0.031)$ and $\mathrm{TiO}_{2} \mathrm{nr}(\mathrm{P}=0.005)$. The results described in this paragraph are all presented in Fig. 6.

ROS production following exposure to fibrous particles. In the present study, all investigated fibrous particles induced ROS production in A549 lung carcinoma cells at a lower level compared with granular particles (Figs. 6 and 7). A potential reason for this finding may be that fibrous particles are comparatively larger and therefore have fewer particles and a smaller surface area. None of the fibrous particles induced ROS levels to a level induced by hematite even at its lowest concentrations. Chrysotile exhibited dose-dependent ROS 
Table III. Characterisation of fibrous particles.

Fibre

Composition

WHO fraction, $\mathrm{F} / \mathrm{mg}$

Glass fibres

$70.0 \% \mathrm{SiO}_{2}, 14.3 \% \mathrm{CaO}, 9.7 \% \mathrm{Na}_{2} \mathrm{O}, 2.5 \% \mathrm{MgO}, 2.3 \% \mathrm{~K}_{2} \mathrm{O}, 1.2 \% \mathrm{Al}_{2} \mathrm{O}_{3}$

260,000

Chrysotile asbestos

$\mathrm{Mg}_{6}\left[\mathrm{Si}_{4} \mathrm{O}_{10}(\mathrm{OH})_{8}\right]$

$800 \times 10^{6}$

Crocidolite asbestos

$\mathrm{Na}_{2} \mathrm{Fe}_{3} \mathrm{Fe}_{2}\left[\mathrm{Si}_{8} \mathrm{O}_{22}(\mathrm{OH})_{2}\right]$

$130 \times 10^{6}$

Characterisation of the fibrous dusts employed in the current study. WHO fraction length $>5 \mu \mathrm{m}$, diameter $<3 \mu \mathrm{m}$ and length to diameter ratio $>3: 1$ as defined in $(35)$.

Table IV. Remaining particles in liquid-REM results, number of particles (\%) standardized on an area of $1 \mathrm{~mm}^{2}$.

\begin{tabular}{|c|c|c|c|c|c|c|c|c|c|c|c|c|c|c|}
\hline \multirow{2}{*}{$\frac{\text { Time }}{\min }$} & \multicolumn{2}{|c|}{ Crocidolite } & \multicolumn{2}{|c|}{ Chrysolite } & \multicolumn{2}{|c|}{ Glass fibres } & \multicolumn{2}{|c|}{$\mathrm{TiO}_{2 \mathrm{ma}}$} & \multicolumn{2}{|c|}{$\mathrm{TiO}_{2 \text { na }}$} & \multicolumn{2}{|c|}{$\mathrm{TiO}_{2 \mathrm{nr}}$} & \multicolumn{2}{|c|}{ Hematite } \\
\hline & $\mathrm{F} / \mathrm{mm}^{2}$ & $\%$ & $\mathrm{~F} / \mathrm{mm}^{2}$ & $\%$ & $\mathrm{~F} / \mathrm{mm}^{2}$ & $\%$ & $\mathrm{P} / \mathrm{mm}^{2}$ & $\%$ & $\mathrm{P} / \mathrm{mm}^{2}$ & $\%$ & $\mathrm{P} / \mathrm{mm}^{2}$ & $\%$ & $\mathrm{P} / \mathrm{mm}^{2}$ & $\%$ \\
\hline 0 & 65,100 & 100 & 17,300 & 100 & 150 & 1,000 & 15,300 & 100 & 94,000 & 100 & 94,000 & 100 & 29,400 & 100 \\
\hline 0.5 & 52,300 & 80 & 15,200 & 88 & 110 & 73 & 6,200 & 41 & 78,700 & 84 & 77,900 & 83 & 29,000 & 99 \\
\hline 1 & 59,900 & 92 & 15,000 & 87 & 80 & 53 & 2,700 & 18 & 72,500 & 77 & 73,000 & 78 & 27,750 & 94 \\
\hline 2 & 56,200 & 86 & 13,700 & 79 & 40 & 27 & 4,400 & 29 & 72,500 & 77 & 72,800 & 77 & 29,000 & 99 \\
\hline 5 & 57,100 & 88 & 15,000 & 87 & 20 & 13 & 5,400 & 35 & 71,900 & 76 & 72,600 & 77 & 29,000 & 99 \\
\hline 10 & 52,400 & 80 & 13,800 & 80 & 50 & 33 & 4,700 & 31 & 72,800 & 77 & 71,600 & 76 & 26,800 & 91 \\
\hline 30 & 50,400 & 77 & 11,800 & 68 & 40 & 27 & 1,750 & 11 & 40,100 & 43 & 40,600 & 43 & 20,900 & 71 \\
\hline 60 & 44,900 & 69 & 11,300 & 65 & 10 & 7 & 1,100 & 7 & 40,200 & 43 & 40,300 & 43 & 19,300 & 66 \\
\hline 120 & 57,500 & 88 & 7,500 & 43 & - & 0 & 1,200 & 8 & 38,600 & 41 & 37,900 & 40 & 16,800 & 57 \\
\hline 180 & 56,700 & 87 & 9,700 & 56 & - & 0 & 800 & 5 & 37,500 & 40 & 37,300 & 40 & 9,500 & 32 \\
\hline 240 & 45,900 & 71 & 5,500 & 32 & - & 0 & 300 & 2 & 29,500 & 31 & 28,700 & 31 & 2,600 & 9 \\
\hline 600 & 43,000 & 66 & 1,900 & 11 & - & 0 & 200 & 1 & 35,200 & 37 & 30,100 & 32 & 450 & 2 \\
\hline
\end{tabular}

$\mathrm{TiO}_{2}$, titanium dioxide; $\mathrm{TiO}_{2}$ ma, microsized $\mathrm{TiO}_{2}$ anatase; $\mathrm{TiO}_{2}$ na, nanosized $\mathrm{TiO}_{2}$ anatase; $\mathrm{TiO}_{2} \mathrm{nr}$, nanosized $\mathrm{TiO}_{2}$ rutile.

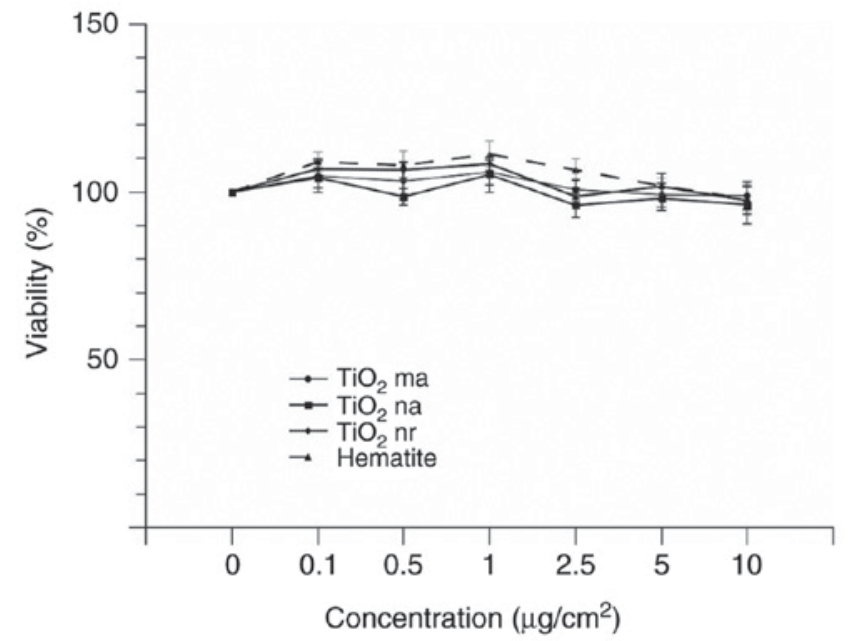

Figure 4. Viability of A549 cells after $24 \mathrm{~h}$ exposure to granular particles at increasing concentrations. Data are presented as the mean \pm standard error of at least seven independent experiments. $\mathrm{TiO}_{2}$, titanium dioxide; $\mathrm{TiO}_{2}$ ma, microsized $\mathrm{TiO}_{2}$ anatase; $\mathrm{TiO}_{2}$ na, nanosized $\mathrm{TiO}_{2}$ anatase; $\mathrm{TiO}_{2} \mathrm{nr}$, nanosized $\mathrm{TiO}_{2}$ rutile.

induction, while the ROS-generating ability of crocidolite did not increase any further above concentrations of $0.5 \mu \mathrm{g} / \mathrm{cm}^{2}$

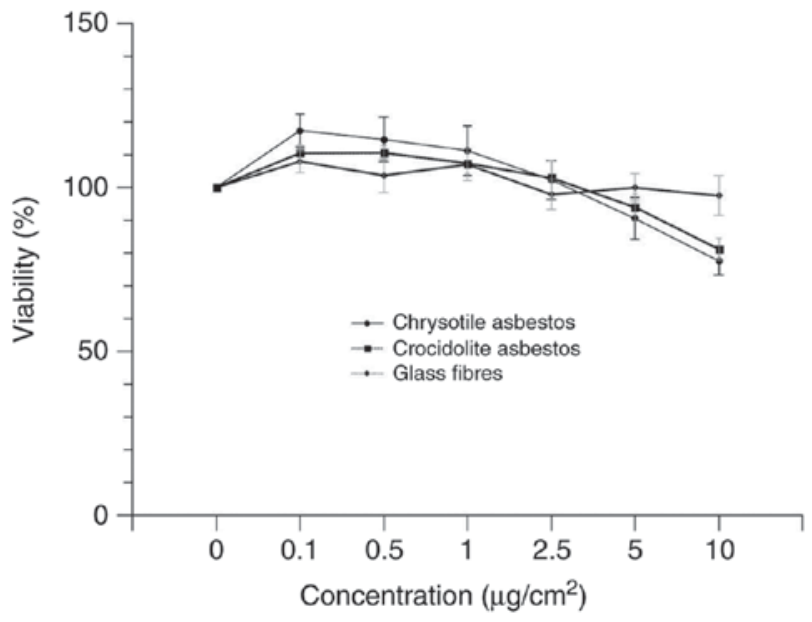

Figure 5. Viability of A549 cells after 24 h exposure to fibrous particles at increasing concentrations. Data are presented as the mean \pm standard error of at least seven independent experiments.

(Fig. 7). No statistically significant differences in ROS generation were observed between chrysotile and crocidolite asbestos. However, ROS-production by crocidolite at concentrations of $0.5,1$ and $5 \mu \mathrm{g} / \mathrm{cm}^{2}$ exceeded those by chrysotile 


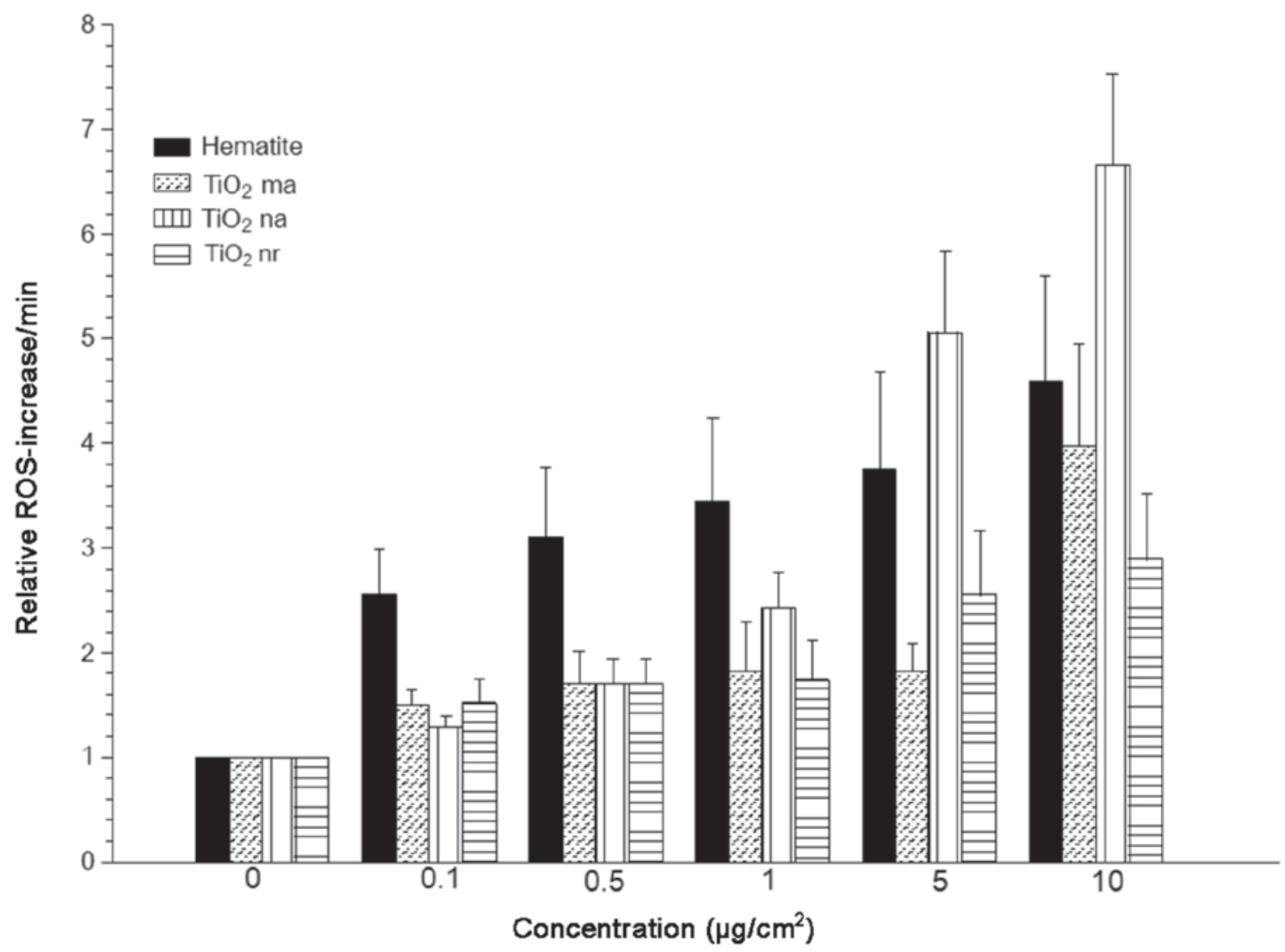

Figure 6. ROS generation induced in A549 cells by exposure to granular particles at increasing concentrations. Horizontal line indicates the upper ROS-generating level of fibrous particles. Data are presented as the mean \pm standard error of at least six independent experiments; $\mathrm{n}=6$ for hematite and $\mathrm{n}=8$ for $\mathrm{TiO}_{2}$ ma, $\mathrm{TiO}_{2}$ na and $\mathrm{TiO}_{2} \mathrm{nr}$. ROS, reactive oxygen species; $\mathrm{TiO}_{2}$, titanium dioxide; $\mathrm{TiO}_{2}$ ma, microsized $\mathrm{TiO}_{2}$ anatase; $\mathrm{TiO}_{2}$ na, nanosized $\mathrm{TiO} \mathrm{O}_{2}$ anatase; $\mathrm{TiO}_{2} \mathrm{nr}$, nanosized $\mathrm{TiO}_{2}$ rutile.

asbestos despite lower fibre concentrations (factor 6,2) and slower sedimentation (Fig. 7). Higher ROS production by crocidolite may be explained by the iron content inducing ROS by Fenton's reaction. Glass fibres did not significantly induce ROS generation in A549 cells at any concentration compared with the control group (Fig. 7).

Gene expression in A549 cells following exposure to granular and fibrous particles. The mRNA expression levels of genes encoding relevant enzymes of the GSH and the thioredoxin systems, as well as SOD, were determined in the present study. Compared with an unexposed control, the examined particles did not alter the mRNA expression levels of GSH peroxidase 2 (GPX2), GSH reductase (GR), GSH S transferase pi (GSTpi), thioredoxin 1 (TRX1), thioredoxin reductase 1 (TRXR1), thioredoxin domain-containing 5 (TXNDC5) or N-Myc downstream gene (NDRG1) within $24 \mathrm{~h}$ of exposure (data not shown). GSH and thioredoxin systems act together with SOD1 and SOD2. RT-qPCR results also demonstrated that SOD1 was marginally, but not significantly, downregulated ( $\mathrm{P}=0.150$; data not shown), while SOD2 was significantly upregulated ( $\mathrm{P}=0.008$; Fig. 8). The SOD2 gene expression, compared with an unexposed control, was significantly upregulated for chrysotile $(\mathrm{P}=0.001)$, crocidolite $(\mathrm{P}=0.030)$, glass fibres $(\mathrm{P}=0.005)$, hematite $(\mathrm{P}=0.037)$ and $\mathrm{TiO}_{2} \mathrm{nr}(\mathrm{P}<0.001)$, as demonstrated in Fig. 8.
Additionally, the mRNA levels of a gene involved in apoptosis were measured. X-linked inhibitor of apoptosis (XIAP), a gene encoding a protein that belongs to a family of apoptotic suppressor proteins (4), was marginally, but not significantly, downregulated ( $\mathrm{P}=0.065$; data not shown).

\section{Discussion}

In the present study the ROS-generating ability of various particles within A549 cells was investigated using the fluorescent probe DCF. It is reported that $\mathrm{H}_{2}$-DCF may be located within the cytosol of the cells and is oxidised by cellular-derived ROS into the highly fluorescent form, DCF (2). The ability of a particle to stimulate cellular oxidant production may be determined by this procedure, but this method cannot distinguish between the oxidant-generating properties of the particles themselves (acellular) and the stimulation of oxidant generation (intracellular). $\mathrm{H}_{2}$-DCF is not prevented from migrating out of cells and therefore may be oxidised by 'acellular' ROS (2). Additionally, it has been reported that $\mathrm{TiO}_{2}$ nanoparticles are rapidly internalised within A549 cells (36). Jiang et al (37) demonstrated that the acellular oxidant-generating capacity of $\mathrm{TiO}_{2}$ nanoparticles was dependent on the crystal phase; a higher ROS activity for $\mathrm{TiO}_{2}$ na was observed compared with $\mathrm{TiO}_{2} \mathrm{nr}$. Of all investigated particles in the present study, at higher concentrations, $\mathrm{TiO}_{2}$ na appeared to exhibit the greatest 


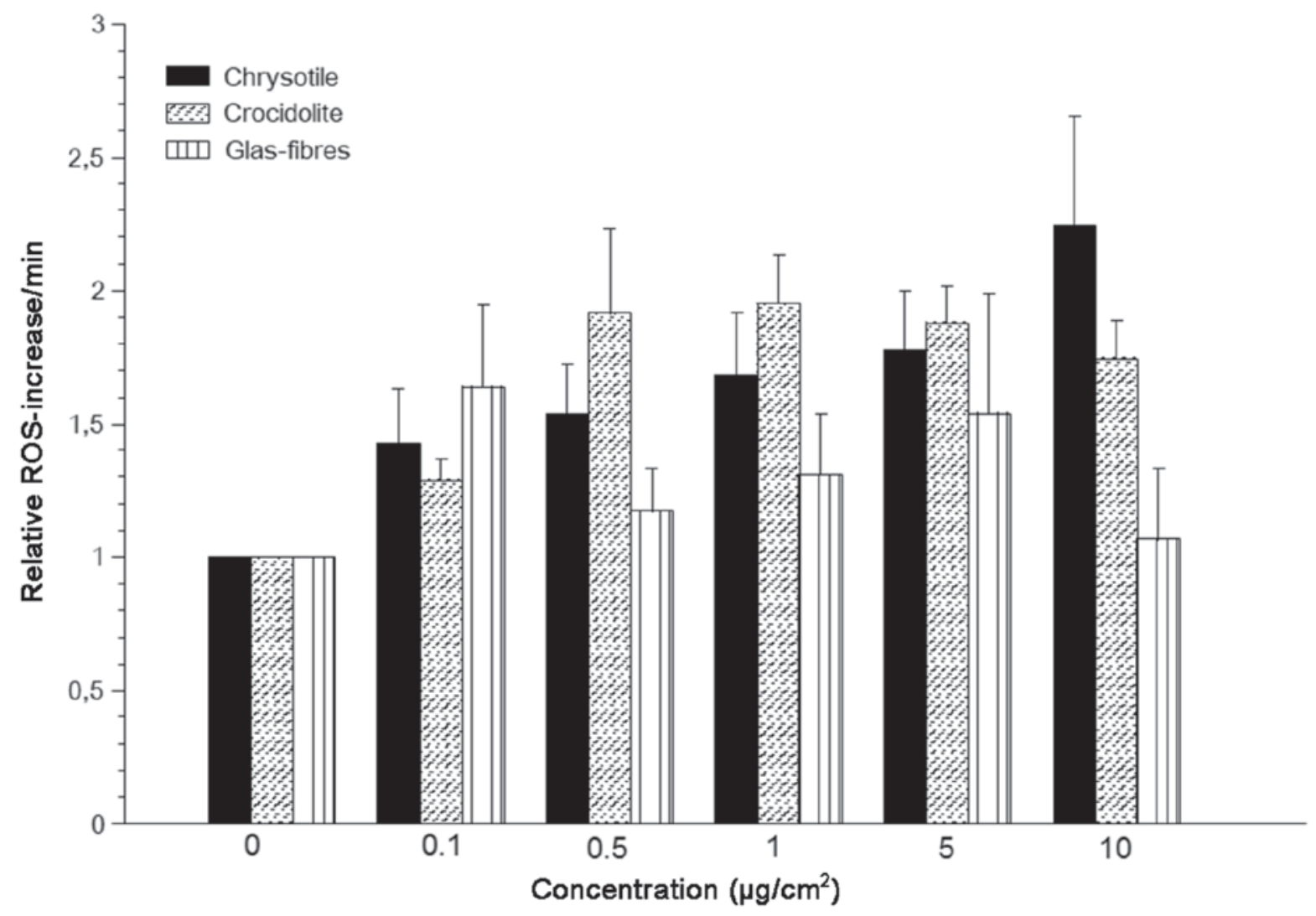

Figure 7. ROS generation induced in A549 cells by exposure to fibrous particles at increasing concentrations. Data are presented as the mean \pm standard error of at least eight independent experiments. ROS, reactive oxygen species.

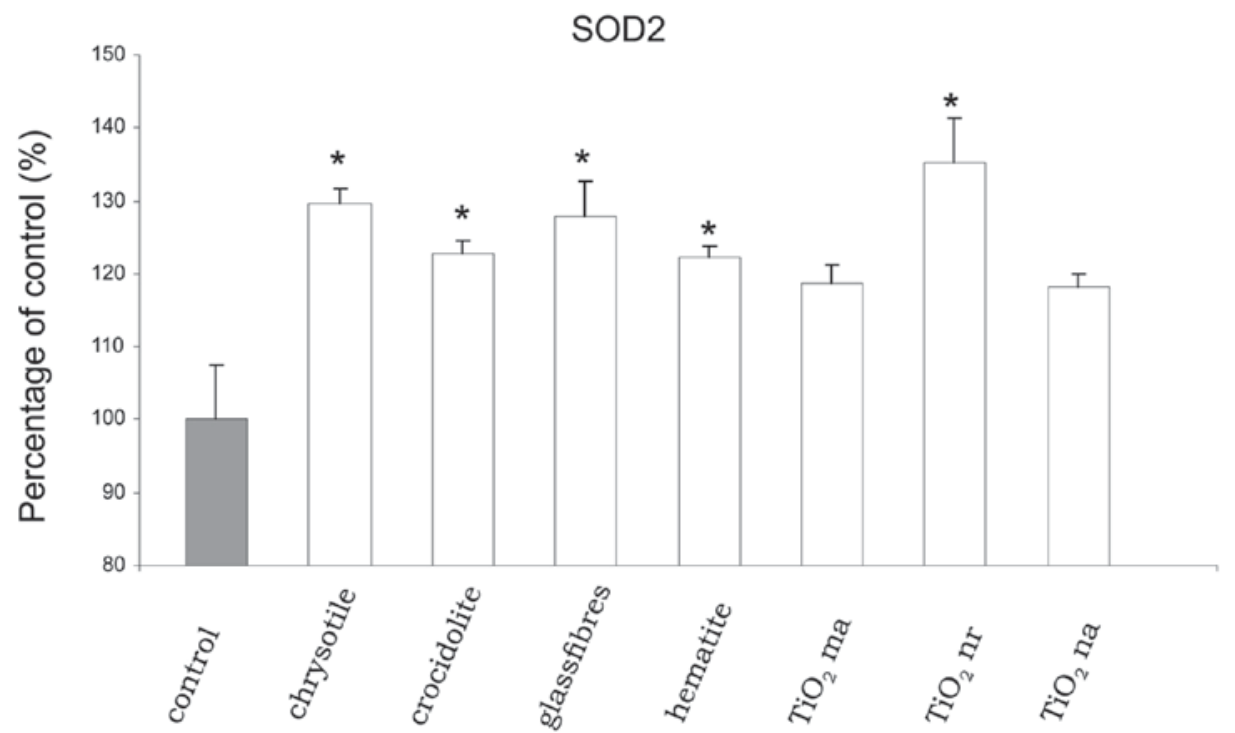

Figure 8. Relative mRNA expression levels of SOD2. The expression of SOD2 is reported as a percentage of unexposed control. Data are presented as the mean \pm standard error of six independent experiments. ${ }^{*} \mathrm{P}<0.05$ vs. control. SOD2, superoxide dismutase 2 ; ma, microsized; na, nanosized; nr, nanosized; TiO ${ }_{2}$, titanium dioxide.

ability to generate ROS within $\mathrm{A} 459$ cells. $\mathrm{As} \mathrm{TiO}_{2}$ nr and $\mathrm{TiO}_{2}$ na have the same size and sinking rates in suspension, other properties may contribute to this effect. Characterisation of the particles revealed that $\mathrm{TiO}_{2}$ na agglomerated to the smallest units of all investigated nanosized particles; therefore, $\mathrm{TiO}_{2}$ na is the sample with the highest particle amount. Additionally, the crystal phase appears to be an important factor. A circular diffraction pattern, as observed for $\mathrm{TiO}_{2}$ na, indicated a lower state of crystallization (disorder). Therefore, the crystalline structure of the $\mathrm{TiO}_{2}$ na particles surface may be more disordered compared with an ideal crystallised particle, such as $\mathrm{TiO}_{2}$ nr. Collectively, $\mathrm{TiO}_{2}$ na has an electronically-defective 
surface structure with reactive bonding properties, that induces high ROS generation. Usually, a disordered surface results in a higher chemical reactivity (38), which is affirmed by the results of ROS experiments in the present study. Wang and Fan (25) reported that anatase appears to be the most active form of $\mathrm{TiO}_{2}$, while rutile is considered to be inert in vitro within cell culture systems. Sayes et al (39) proposed that the crystal phase of nanosized $\mathrm{TiO}_{2}$ particles, rather than the surface area, is the most important parameter for toxicity; $\mathrm{TiO}_{2}$ na particles induced an $\mathrm{LC}_{50}$ of $3,6 \mu \mathrm{g} / \mathrm{ml}$, while $\mathrm{TiO}_{2} \mathrm{nr}$ particles induced an $\mathrm{LC}_{50}$ of $550 \mu \mathrm{g} / \mathrm{ml}$. A greater toxicity of $\mathrm{TiO}_{2}$ na compared to $\mathrm{TiO}_{2}$ nr was observed within A549 cells, as measured by lactate dehydrogenase (LDH) release and a colorimetric assay for assessing cell metabolic activity via an MTT assay.

Using the MTT assay, Simon-Deckers et al (36) reported the cell death rate after $48 \mathrm{~h}$ of exposure to $100 \mu \mathrm{g} / \mathrm{ml} \mathrm{TiO}$ na $\left(\mathrm{TiO}_{2} 12 \mathrm{~nm}, 26 \%\right.$ and $\left.\mathrm{TiO}_{2} 25 \mathrm{~nm}, 24 \%\right)$ to be slightly more toxic compared with exposure to $\mathrm{TiO}_{2} \mathrm{nr}\left(\mathrm{TiO}_{2} 68 \mathrm{~nm}\right.$, $10 \%)$. However, an XTT assay revealed only a low level of cytotoxicity ( $15 \%$ cell death after $48 \mathrm{~h}$ with $100 \mu \mathrm{g} / \mathrm{ml}$ ) for all investigated nanoparticles. After $6 \mathrm{~h}$ of exposure, $\mathrm{TiO}_{2}$ particles, independent of their size (12-140 nm), were observed in the cytoplasm of the majority of cells. Theses variations in cytotoxicity may have been associated with particle size and potentially the internalisation pathway; smaller $\mathrm{TiO}_{2}$ particles (12 and $25 \mathrm{~nm})$ were markedly more toxic than larger $\mathrm{TiO}_{2}$ particles (140 nm) (36).

In the present study, the results demonstrated that exposure of A549 cells to hematite for $24 \mathrm{~h}$ led to the generation of ROS in a dose-dependent manner. Of all the particles investigated, hematite exhibited the greatest ability to induce ROS generation at concentrations $\leq 1 \mu \mathrm{g} / \mathrm{cm}^{2}$ due to its iron content, which allows the induction of ROS via Fenton's reaction. Concerning the toxicity of hematite, there are contrasting results in previous studies. Khan et al (40) demonstrated that iron oxide nanoparticles with an average size between 30 and $65 \mathrm{~nm}$ induced ROS generation in a time-(1-24 h) and concentration-(10-100 $\mu \mathrm{g} / \mathrm{ml})$ dependent manner within A549 cells. Wottrich et al (41) demonstrated the uptake of hematite particles with an average size of $70 \mathrm{~nm}(50-90 \mathrm{~nm})$ into A549 cells, where they formed agglomerates. The cytotoxicity of hematite exposure $(24 \mathrm{~h})$, measured by LDH release and the induction of interleukin- 6 and interleukin- 8 release, were affected by the particles in a dose-dependent manner (6.1 and $121 \mu \mathrm{g} / \mathrm{cm}^{2}$ ). The authors concluded that particle size and particle composition, respectively, may be responsible for the biological effects observed (41). However, Freyria et al (42) reported that hematite particles $\leq 100 \mu \mathrm{g} / \mathrm{cm}^{2}$ did not increase LDH release within $24 \mathrm{~h}$ in A549 cells and are therefore a poorly reactive with low toxicity. They also observed that reducing the size from 1-2 $\mu \mathrm{m}$ to $80-100 \mathrm{~nm}$ did not cause increases in the surface reactivity associated with oxidative stress, including the production of free radicals and cysteine depletion. All hematite particles were considered to be non-toxic and did not induce apoptosis or DNA damage in an A549 cell model within 24 h. Furthermore, Karlson et al (43) reported that there was no or low toxicity, as observed by trypan blue staining for iron oxide particles $\left(\mathrm{Fe}_{2} \mathrm{O}_{3}\right.$ and $\mathrm{Fe}_{3} \mathrm{O}_{4}$, size 30-60 nm), when A549 cells were exposed at concentrations from $20-40 \mu \mathrm{g} / \mathrm{cm}^{2}$ over $18 \mathrm{~h}$. Additionally, an increase in intracellular ROS production was not observed after $4 \mathrm{~h}$ exposure to 20 and $40 \mu \mathrm{g} / \mathrm{cm}^{2}$ $\mathrm{Fe}_{2} \mathrm{O}_{3}$ or $\mathrm{Fe}_{3} \mathrm{O}_{4}$ nanoparticles. Notably, nanoscaled hematite differs by its manufacturing process and the $\mathrm{H}_{2} \mathrm{O}$ content of its crystal lattice (31), which may explain the different outcomes reported.

In general, fibrous particles appear to have a lower ability to generate ROS than granular particles within A549 cells. Herzog et al (44) observed only a low oxidative stress response within A549 cells following crocidolite exposure, but the incubation time of the cells was limited to $1 \mathrm{~h}$. Furthermore, Baldys et al (45) hypothesised that the apoptosis of A549 cells mediated by crocidolite may also require the inactivation of important cell growth and differentiation pathways, rather than solely being a result of oxidant production. These findings support the results from our previous study, in which we demonstrated that granular particles induced the signalling pathways responsible for oxidative/metabolic stress and inflammation, while fibrous particles also altered the signalling pathways responsible for carcinogenesis and proliferation (30). It is clear that asbestos fibres do induce ROS significantly in A549 cells. In the present study, asbestos fibres appeared to induce ROS to a lower extent than granular particles, which may be explained by fewer particles and subsequent lower surface area in fibrous particles compared with granular particles. The generation of ROS induced by asbestos is considered to be a major mediator of asbestos-associated toxicity through at least two primary mechanisms, with one being that the iron content of the fibres catalyses ROS production at the fibre surface and induces certain inflammatory cells, including pulmonary alveolar macrophages and neutrophils, which release further ROS in an attempt to remove these fibres $(19,23)$. As aforementioned, in the current study, intracellular levels of ROS within A549 cells were analysed after $24 \mathrm{~h}$ of incubation, which may explain the reduced levels of ROS production following exposure to fibrous particles compared with granular particles. Fibrous particles are comparatively larger and therefore have a lower particle number compared with granular particles. The lower surface area and geometrical form (needle-like) of fibres also lead to weaker contact with the cell surface compared with granular particles, which may also contribute to the differences observed.

In the present study, glass fibres did not reduce cell viability or induce ROS generation in A549 cells significantly. Conversely, Rapisarda et al (12) reported that exposure to glass fibres $\left(2.1,21\right.$ and $\left.42 \mu \mathrm{g} / \mathrm{cm}^{2}\right)$ over $72 \mathrm{~h}$ significantly reduced cell viability, as observed in an MTT assay; increased oxidative stress within A549 cells was also observed via DCF fluorescence analysis. Notably, the glass fibres employed in the present study were free of boron oxide $\left(\mathrm{B}_{2} \mathrm{O}_{3}\right)$, while the glass fibres used by Rapisarda et al (12) contained a large amount (13\%) of $\mathrm{B}_{2} \mathrm{O}_{3}$. Additionally, it is possible that ROS may have been induced as a result of the longer exposure duration of $72 \mathrm{~h}$, compared with the exposure duration of $24 \mathrm{~h}$ applied in the present study.

It has been reported that at low levels of ROS production, cells may initiate a protective response to ensure their survival, while excessive levels of ROS causes damage to cellular compounds $(1,46)$. For the gene expression analyses in the present study, a relatively low exposure concentration of $1 \mu \mathrm{g} / \mathrm{cm}^{2}$ for fibrous and $0.1 \mu \mathrm{g} / \mathrm{cm}^{2}$ for granular particles was selected. The idea was to determine whether protective alterations in RNA expression occur at low effect levels (ROS generation). 
Therefore, the mRNA levels of the genes coding for antioxidant and antiapoptotic enzymes were analysed following exposure of A549 cells to each particle for $24 \mathrm{~h}$. Investigating antioxidant enzymes of the GSH and the thioredoxin system, as well as the SOD enzymes, the results demonstrated that only SOD2 expression was significantly upregulated by certain particles, while SOD1 expression was rather stable or marginally downregulated. Therefore, SOD2 rather than SOD1 can be used as a marker for ROS-inducing processes at low concentrations. This finding is consistent with the consideration that SOD2 is more sensitive to intracellular or environmental stimuli, while SOD1 is considered to be expressed constitutively (47). Also consistent with this, Hu et al (4) demonstrated upregulated transcript levels of SOD2 and stable transcript levels of SOD1 in A549 cells under resveratrol treatment for $24 \mathrm{~h}$. XIAP is a potent inhibitor of apoptosis and is able to directly inhibit the initiation and execution of the caspase cascade $(48,49)$. Under high dosage of resveratrol (for $24 \mathrm{~h}$ ), an increased mRNA level of XIAP has been reported in A549 cells (4). This protective effect might be true for high dosage but was not observed in the low exposure concentration of granular and fibrous particles employed in the presents study.

In conclusion, the ability of biopersistent granular dust to generate ROS is due to the number of particles as well as substance-specific properties. The crystalline surface structure of the particles may be a factor that influences their ability to generate ROS. Hematite induced high ROS production even at low concentrations in the present study, which may be attributed to the Fenton's reactions that occur due to the iron content of hematite. As fibrous particle are comparatively larger and have fewer particles and a lower surface area compared with granular particles, they induce ROS at a much lower level. In the case of crocidolite and chrysotile asbestos, the lower sinking rate under experimental conditions should also be considered. The present study demonstrated that particles of the same composition and size may induce different effects in biological systems. Therefore, it is of high importance to nvestigate and characterize these particles in more detail further.

\section{Acknowledgements}

Certain results in this manuscript were included in the thesis of Mrs. Julia Putzier. The authors thank Mrs. Monika Philipp and Mrs. Daniela Schreiber (Institute and Outpatient Clinic for Occupational and Social Medicine, Justus-Liebig University and Physiologisches Institut, Justus-Liebig-Universität Giessen) for their technical assistance in cell culture experiments and Dipl. Ing. Natalia Haibel, Dipl. Ing. Rolf Arhelger and Dipl. Ing. Bernd Brückel (Institute and Outpatient Clinic for Occupational and Social Medicine, Justus-Liebig University, Giessen) for their work in particle characterisation.

\section{Funding}

No funding was received.

\section{Availability of data and materials}

The datasets used and/or analyzed during the current study are available from the corresponding author on reasonable request.

\section{Authors' contributions}

SH provided the conception and administrative support, provision of study materials, acquisition, data analysis and interpretation of data and write the manuscript. SW provided the conception and design, support in ROS analysis and drafted the manuscript. JP provided the acquisition, collection and assembly of data and interpretation of data. DW provided the conception, acquisition, and characterisation of dust material and data interpretation. HM provided the conception and design, and drafted the manuscript. JS provided the conception and design, data analysis and interpretation, critically revised and partially wrote the manuscript. All authors read and approved the final manuscript.

\section{Ethics approval and consent to participate}

Not applicable.

\section{Consent for publication}

Not applicable.

\section{Competing interests}

The authors declare that they have no competing interests.

\section{References}

1. Roesslein M, Hirsch C, Kaiser JP, Krug HF and Wick P: Comparability of in vitro tests for bioactive nanoparticles: A common assay to detect reactive oxygen species as an example. Int J Mol Sci 14: 24320-24337, 2013.

2. Held P: An Introduction to Reactive Oxygen Species. Measurement of ROS in Cells. White Paper. BioTek Instruments, Inc., Winooski, VT, 2015.

3. Nel A, Xia T, Mädler L and Li N: Toxic potential of materials at the nanolevel. Science 311: 622-627, 2006.

4. Hu Y, Rahlfs S, Mersch-Sundermann V and Becker K: Resveratrol modulates mRNA transcripts of genes related to redox metabolism and cell proliferation in non-small-cell lung carcinoma cells. Biol Chem 388: 207-219, 2007.

5. Lu J and Holmgren A: The thioredoxin antioxidant system. Free Radic Biol Med 66: 75-87, 2014.

6. Becker K, Gromer S, Schirmer RH and Müller S: Thioredoxin reductase as a pathophysiological factor and drug target. Eur J Biochem 267: 6118-6125, 2000

7. Xiao GG, Wang M, Li N, Loo JA and Nel AE: Use of proteomics to demonstrate a hierarchical oxidative stress response to diesel exhaust particle chemicals in a macrophage cell line. J Biol Chem 278: 50781-50790, 2003.

8. Oberdörster G, Oberdörster E and Oberdörster J: Nanotoxicology: An emerging discipline evolving from studies of ultrafine particles. Environ Health Perspect 113: 823-839, 2005.

9. Phaniendra A, Jestadi DB and Periyasamy L: Free radicals: Properties, sources, targets, and their implication in various diseases. Indian J Clin Biochem 30: 11-26, 2014.

10. Murphy MP, Holmgren A, Larsson NG, Halliwell B, Chang CJ, Kalyanaraman B, Rhee SG, Thornalley PJ, Partridge L, Gems D, et al: Unraveling the biological roles of reactive oxygen species. Cell Metab 13: 361-366, 2011.

11. Federico A, Morgillo F, Tuccillo C, Ciardiello F and Loguercio C: Chronic inflammation and oxidative stress in human carcinogenesis. Int J Cancer 121: 2381-2386, 2007.

12. Rapisarda V, Loreto C, Ledda C, Musumeci G, Bracci M, Santarelli L, Renis M, Ferrante M and Cardile V: Cytotoxicity, oxidative stress and genotoxicity induced by glass fibers on human alveolar epithelial cell line A549. Toxicol In Vitro 29: 551-557, 2015. 
13. Knaapen AM, Borm PJ, Albrecht C and Schins RP: Inhaled particles and lung cancer. Part A: Mechanisms. Int J Cancer 109: 799-809, 2004.

14. DFG: List of MAK and BAT values. List of MAK and BAT Values 2016: Permanent Senate Commission for the Investigation of Health Hazards of Chemical Compounds in the Work Area. Report No. 52. Wiley-VCH, Weinheim, 2016.

15. Walter D: Primary particles-Agglomerates-Aggregates. In Nanomaterials. Deutsche Forschungsgemeinschaft (DFG) (ed) Wiley-VCH Verlag GmbH \& Co. KGaA., Weinheim, pp9-24, 2013.

16. Stone V, Johnston $\mathrm{H}$ and Clift MJ: Air pollution, ultrafine and nanoparticle toxicology: Cellular and molecular interactions. IEEE Trans Nanobioscience 6: 331-340, 2007.

17. Oberdörster G: Pulmonary effects of inhaled ultrafine particles. Int Arch Occup Environ Health 74: 1-8, 2001.

18. Mossman BT and Churg A: Mechanisms in the pathogenesis of asbestosis and silicosis. Am J Respir Crit Care Med 157: 1666-1680, 1998.

19. Kamp DW: Asbestos-induced lung diseases: An update. Transl Res 153: 143-152, 2009.

20. Shukla A, MacPherson MB, Hillegass J, Ramos-Nino ME, Alexeeva V, Vacek PM, Bond JP, Pass HI, Steele C and Mossman BT: Alterations in gene expression in human mesothelial cells correlate with mineral pathogenicity. Am J Respir Cell Mol Biol 41: 114-123, 2009.

21. Robledo R and Mossman B: Cellular and molecular mechanisms of asbestos-induced fibrosis. J Cell Physiol 180: 158-166, 1999.

22. Lemaire I and Ouellet S: Distinctive profile of alveolar macrophage-derived cytokine release induced by fibrogenic and nonfibrogenic mineral dusts. J Toxicol Environ Health 47: 465-478, 1996

23. Kamp DW and Weitzman SA: The molecular basis of asbestos induced lung injury. Thorax 54: 638-652, 1999.

24. Riedel E: Allgemeine und Anorganische Chemie. Walter de Gruyter, Berlin, New York, 1999.

25. Wang $\mathbf{J}$ and Fan Y: Lung injury induced by $\mathrm{TiO} 2$ nanoparticles depends on their structural features: Size, shape, crystal phases, and surface coating. Int J Mol Sci 15: 22258-22278, 2014.

26. Liochev SL: The role of iron-sulfur clusters in in vivo hydroxyl radical production. Free Radic Res 25: 369-384, 1996.

27. Liochev SI and Fridovich I: The relative importance of $\mathrm{HO}^{*}$ and ONOO-in mediating the toxicity of $\mathrm{O}^{*}$-. Free Radic Biol Med 26 777-778, 1999

28. Liochev SI and Fridovich I: The Haber-Weiss cycle-70 years later: An alternative view. Redox Rep 7: 55-57, 59-60, 2002.

29. Schneider J, Walter D, Brückel B and Rödelsperger K: Primary particles and their agglomerate formation as modifying risk factors of nonfibrous nanosized dust. J Toxicol Environ Health A 76: 131-141, 2013.

30. Helmig S, Dopp E, Wenzel S, Walter D and Schneider J: Induction of altered mRNA expression profiles caused by fibrous and granular dust. Mol Med Rep 9: 217-228, 2014.

31. Walter D: Characterization of synthetic hydrous hematite pigments. Thermochimica Acta 445: 195-199, 2006.

32. Rhodes JM: Introduction to Patricle Technology. 2nd edition. John Wiley \& Sons Ltd., Chichester, 2008.

33. Helmig S, Hadzaad B, Döhrel J and Schneider J: Relative quantification of Cytochrome P450 1B1 gene expression in peripheral leukocytes using lightcycler. Cancer Genomics Proteomics 6: 13-17, 2009.

34. Livak KJ and Schmittgen TD: Analysis of relative gene expression data using real-time quantitative PCR and the 2(-Delta Delta C(T)) method. Methods 25: 402-408, 2001.
35. Rödelsperger K, Brückel B, Podhorsky S and Schneider J: Charakterisierung von ultrafeinen Partikeln für den Arbeitsschutz-Teil 2. Bundesanstalt für Arbeitsschutz und Arbeitsmedizin, Dortmund/Berlin/Dresden, 2009. https:// www.baua.de/DE/Angebote/Publikationen/Berichte/F2075. pdf?_blob=publicationFile.

36. Simon-Deckers A, Gouget B, Mayne-L'hermite M, Herlin-Boime $N$, Reynaud $C$ and Carrière $M$ : In vitro investigation of oxide nanoparticle and carbon nanotube toxicity and intracellular accumulation in A549 human pneumocytes. Toxicology 253: 137-146, 2008.

37. Jiang J, Oberdörster G, Elder A, Gelein R, Mercer P and Biswas P: Does nanoparticle activity depend upon size and crystal phase? Nanotoxicology 2: 33-42, 2008.

38. Ertl G and Knözinger H: Handbook of Heterogeneous Catalysis. Wiley-VCH, Weinheim, 1997.

39. Sayes CM, Wahi R, Kurian PA, et al: Correlating nanoscale titania structure with toxicity: a cytotoxicity and inflammatory response study with human dermal fibroblasts and human lung epithelial cells. Toxicol Sci 92: 174-185, 2006.

40. Khan MI, Mohammad A, Patil G, Naqvi SA, Chauhan LK and Ahmad I: Induction of ROS, mitochondrial damage and autophagy in lung epithelial cancer cells by iron oxide nanoparticles. Biomaterials 33: 1477-1488, 2012.

41. Wottrich R, Diabaté S and Krug HF: Biological effects of ultrafine model particles in human macrophages and epithelial cells in mono- and co-culture. Int J Hyg Environ Health 207: 353-361, 2004.

42. Freyria FS, Bonelli B, Tomatis M, et al: Hematite nanoparticles larger than $90 \mathrm{~nm}$ show no sign of toxicity in terms of lactate dehydrogenase release, nitric oxide generation, apoptosis, and comet assay in murine alveolar macrophages and human lung epithelial cells. Chem Res Toxicol 25: 850-861, 2012.

43. Karlsson HL, Cronholm P, Gustafsson J and Moller L: Copper oxide nanoparticles are highly toxic: a comparison between metal oxide nanoparticles and carbon nanotubes. Chem Res Toxicol 21: 1726-1732, 2008.

44. Herzog E, Byrne HJ, Davoren M, Casey A, Duschl A and Oostingh GJ: Dispersion medium modulates oxidative stress response of human lung epithelial cells upon exposure to carbon nanomaterial samples. Toxicol Appl Pharmacol 236: 276-281, 2009.

45. Baldys A, Pande P, Mosleh T, Park SH and Aust AE: Apoptosis induced by crocidolite asbestos in human lung epithelial cells involves inactivation of Akt and MAPK pathways. Apoptosis 12: 433-447, 2007

46. Otsuki T, Maeda M, Murakami S, Hayashi H, Miura Y, Kusaka M, Nakano T, Fukuoka K, Kishimoto T, Hyodoh F, et al: Immunological effects of silica and asbestos. Cell Mol Immunol 4: 261-268, 2007.

47. Zelko IN, Mariani TJ and Folz RJ: Superoxide dismutase multigene family: A comparison of the CuZn-SOD (SOD1), Mn-SOD (SOD2), and EC-SOD (SOD3) gene structures, evolution, and expression. Free Radic Biol Med 33: 337-349, 2002.

48. Eckelman BP, Salvesen GS and Scott FL: Human inhibitor of apoptosis proteins: Why XIAP is the black sheep of the family. EMBO Rep 7: 988-994, 2006.

49. Caballero-López MJ, Nieto-Diaz M, Yunta M, Reigada D, Muñoz-Galdeano T, Del Águila Á, Navarro-Ruíz R, Pita-Thomas W, Lindholm D and Maza RM: XIAP interacts with and regulates the activity of FAF1. Biochim Biophys Acta 1864: 1335-1348, 2017 